\title{
Effects of sunflower oil supplementation on performance, nutrient digestibility, rumen fermentation and blood metabolites in crossbred (Macheng Black x Boer) goats
}

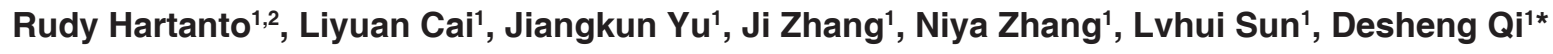 \\ ${ }^{1}$ Department of Animal Nutrition and Feed Science, Faculty of Animal Science and Technology, Huazhong Agricultural University, P.R. China, \\ ${ }^{2}$ Department of Animal Science, Faculty of Animal and Agricultural Sciences, Diponegoro University, Indonesia
}

\section{A B S T R A C T}

\begin{abstract}
This study aims to determine the effects of sunflower oil supplementation on performance, nutrient digestibility, rumen fermentation and blood metabolites in crossbred goats. Randomized complete block with sub sampling; with 3 treatments, 3 sub sampling and 4 experiment periods as blocks were conducted using 9 crossbred (Boer $\mathrm{x}$ Macheng Black) female goats with an initial body weight (BW) around $20.96 \pm 1.79 \mathrm{~kg}$ were used in our experiment. Three levels of sunflower oil supplementation (sunflower oil = $\mathrm{S}$; 0 , 33, and $66 \mathrm{~g} \mathrm{~kg}^{-1}$ of dry matter (DM)) to commercial complete feed were used for the treatment arrangement. Every experiment period was done in three weeks and rested one week before the next period at the individual cages. Nutrient digestibility (except ether extract (EE)), protozoa counts and ammonia- $\mathrm{N}\left(\mathrm{NH}_{3}-\mathrm{N}\right)$ concentration were decreased; molar proportions of volatile fatty acids (VFA) were changed; blood metabolites (except cholesterol) were not affected by sunflower oil supplementation. The inclusion of sunflower oil had no adverse effect on performance; thus improve dry matter intake (DMI), average daily gain (ADG), feed efficiency (FE) which S33 was better than SO and S66. In conclusion, the best result was sunflower oil supplementation $33 \mathrm{~g} \mathrm{~kg}^{-1}$ of DM (S33); because compared with control, improve ADG $(31.79 \%)$ and FE (15.32\%). Sunflower oil supplementation could improve performance by positively affecting the ruminal on rumen fermentation in crossbred (Boer $x$ Macheng Black) female goats.
\end{abstract}

Keywords: Sunflower oil; Goat performance; Nutrient digestibility; Rumen fermentation; Blood metabolites

\section{INTRODUCTION}

Improved goat performance is very important in goat farms, including in China. It was affected by quantity and quality of diets. Sufficient energy supply is very important in the ruminant diets. The problems of energy supply in ruminants could be solved with dietary fat, in example supplementation of vegetable oil to the diets, including sunflower oil. Moreover, the dietary fat is low priced and easy to find (NRC, 2007; Adeyemi et al., 2016). In addition to increase energy supply, the addition of vegetable oil is used to serve as carriers and to facilitate the digestion process of fat-soluble ingredients (Palmquist, 1987) and ruminal acidosis prevention (Chilliard, 1993). Performance of goat was improved by supplementation of vegetable oil to the diets (Cozma et al. (2015); Adeyemi et al. (2016)). In
2014, vegetable oil production in China is approximately 22.52 million tons, included sunflower oil 299,848 tons (FAOSTAT, 2017). Sunflower oil is rich in linoleic and oleic which are unsaturated fatty acids (Roy et al., 2013). Although inclusion oil on dietary could increase energy density of the diets, increasing source of unsaturated fatty acids may alter microbial rumen (Hristov et al., 2013).

The inclusion of vegetable oil on ruminant diets (4-8\% of dry matter $(\mathrm{DM})$ that increase the fat content of the diet up to $6.35-11.11 \%$ ) had no effect on nutrient intake and nutrient digestibility, alter rumen fermentation, decrease rumen protozoa, change microbial population, change serum metabolites, but improve average daily gain (ADG) and feed efficiency (FE) (Martin et al., 2008; Pilajun and Wanapat, 2011; Fiorentini et al., 2014; Cleef et al., 2016;

\footnotetext{
*Corresponding author:

Desheng Qi, Department of Animal Nutrition and Feed Science, College of Animal Science and Technology, Huazhong Agricultural University, Wuhan, Hubei 430070, P.R. China. Email: qds@mail.hzau.edu.cn
}

Received: 14 September 2018; $\quad$ Accepted: 18 December 2019 
Adeyemi et al., 2016; Ferreira et al., 2016). Roy et al. (2013) reported that supplementation of sunflower oil (4.5\% of DM) could improve FE, increase serum triglyceride and cholesterol of Black Bengal goats. In a previous study, addition of sunflower oil ( $5 \%$ of dry matter intake (DMI)) could increase propionate, decrease acetate: propionate and rumen $\mathrm{pH}$ of beef cattle (McGinn et al., 2004).

Sunflower oil has good potential as feed supplement of local goats in china. Therefore, the purpose of this study was to determine the effects of sunflower oil supplementation on performance, nutrient digestibility, rumen fermentation and blood metabolites in crossbred (Macheng Black x Boer) goats.

\section{MATERIALS AND METHODS}

\section{Animals, experimental design, feeding treatments and sampling procedures}

This experiment was completed at the individual cages using nine crossbred (Macheng Black x Boer) female goats with an initial body weight (BW) around $20.96 \pm 1.79 \mathrm{~kg}$. The experiment was carried out over 4 months by randomized complete block with sub sampling; with 3 treatments, 3 sub sampling and 4 experiment periods as blocks. The treatments were 3 sunflower oil supplementations (sunflower oil $=\mathrm{S}$; 0 , 33 , and $66 \mathrm{~g} \mathrm{~kg}^{-1}$ of dry matter (DM)) to commercial complete feed. Furthermore, every experiment period was done in three weeks and rested one week before the next period.

The goats allowed the basal diet was commercial complete feed (Wuhan Wan Qian Jia Xing Bio-Technology Co. Ltd., China) with nutrient content: dry matter (DM) 86.99\%, crude protein (CP) $17.70 \%$, ether extract (EE) $1.83 \%$, crude fiber (CF) 17.09\%, nitrogen free extract (NFE) 36.96\%, ash $13.41 \%$, calcium $1.31 \%$, phosphorus $0.77 \%$, neutral detergent fiber (NDF) 47.21\%, acid detergent fiber (ADF) $27.80 \%$, and gross energy (GE) $15.13 \mathrm{MJ} \mathrm{kg}^{-1}$. Sunflower oil was obtained from commercial source (MIGHTY Brand, China). Fatty acids compositions of sunflower oil were palmitic $6 \%$, stearic $5 \%$, oleic $20 \%$ and linoleic $69 \%$ (NSA, 2017). Feed was offered twice daily (08:00 and 17:00 h) totally at $4 \%$ of BW. Furthermore, the diet and refusals samples were retained in every experiment period for DM content determination. Quantities of feed offered and refused were recorded daily for each goat. Therefore, the dry matter intake (DMI) was calculated daily for each goat as: DM offered - DM refused. Before the morning feeding at the beginning and at 21-d intervals until the end of the experimental period, goats were weighed immediately and these weights were used to calculate BW changes and average daily gain of goats.
In every experiment period (block), the external marker was used for the determination digestibility of nutrients, which prepared using chromic oxide $\left(\mathrm{Cr}_{2} \mathrm{O}_{3}\right)$ as many as $0.3 \%$ of the diet. Treatments diet including an external marker was given on days 15 to 19. Rumen parameters, such as volatile fatty acids (VFA), ammonia- $\mathrm{N}\left(\mathrm{NH}_{3}-\mathrm{N}\right)$, $\mathrm{pH}$ and protozoa were measured by collecting rumen fluid of each animal which was performed before the morning feeding on day 20. Furthermore, the $\mathrm{pH}$ was determined immediately using a digital $\mathrm{pH}$ meter (Model Sartorius PB-10, Germany). Ciliate protozoa were counted by a $0.2-\mathrm{mm}$ depth counting chamber (hemocytometer) with the method of the methylgreen-formalin-saline (MFS) solution (Ogimoto and Imai, 1981). $\mathrm{NH}_{3}-\mathrm{N}$ concentration was analyzed by the phenol hypochlorite method (Chaney and Marbach, 1962). A gas chromatography (Model GC 2010, Shimadzu, Japan) was used to determine VFA as follows by Yang and Choong (2001). Ten mL blood was collected by jugular vein puncture in a test tube before the morning feeding on day 21 from each animal. In addition, the samples were analyzed for glucose, triglyceride, cholesterol, total protein (TP), blood urea nitrogen (BUN), alanine transaminase (ALT), aspartate transaminase (AST) of serum by using standard test kits (DiaSys Diagnostic Systems) on an Automatic biochemical analyzer (Hitachi 7100 , Japan). All parameters were done on 3 sub sampling in every experiment period.

\section{Statistical analysis}

The general linear models (GLM) procedure of a randomized complete block with sub sampling from SAS was used for performing computations for all variables (SAS, 2008). The means were compared using Duncan's Range test. Treatment effects and difference among means were declared significant at $P<0.05$. The statistical model was $Y_{i j k}=\mu+\tau_{i}+\beta_{j}+\varepsilon_{i j}+\delta_{i j i k}$; where $Y_{i j k}$ is the dependent variables, $\mu$ is the overall mean, $\tau_{i}$ is the $S$ treatment effect $(i=1-3), \beta_{\mathrm{j}}$ is the block effect $(\mathrm{j}=1-4)$, $\varepsilon_{\mathrm{ij}}$ is the experimental error, $\delta_{\mathrm{i} j \mathrm{k}}$ is the sub sampling error $(\mathrm{k}=1-3)$. Furthermore, the initial body weight was used as a covariate $\mathrm{b}(\mathrm{x}-\mathrm{x} \bar{x})$ in the model for analyzing data on performance.

\section{RESULTS AND DISCUSSION}

\section{Rumen parameters}

Table 1 shows rumen parameters of crossbreed (Boer $\mathrm{x}$ Macheng Black) female goats. Sunflower oil supplementation had effect on protozoa counts $(\mathrm{P}<0.001), \mathrm{NH}_{3}-\mathrm{N}$ $(\mathrm{P}<0001)$, total VFA $(\mathrm{P}=0.036)$. No differences in rumen $\mathrm{pH}(\mathrm{P}=0.122)$ and acetate: propionate $(\mathrm{P}=0.171)$ were observed among levels of sunflower oil (S0, S33 and S66). Changes in the proportion of VFA and protozoa counts by sunflower oil supplementation could improve 
Hartanto, et al.

Table 1: Rumen fermentation variables of crossbreed (Macheng Black x Boer) female goats fed commercial diets with various supplemental sunflower oil

\begin{tabular}{|c|c|c|c|c|c|}
\hline \multirow[t]{2}{*}{ Observed variables* } & \multicolumn{3}{|c|}{$\mathrm{S}, \mathbf{g ~ k g}^{-1} \mathrm{DM}^{* *}$} & \multirow[t]{2}{*}{ SEM $^{\star \star \star *}$} & \multirow[t]{2}{*}{ P-value } \\
\hline & 0 & 33 & 66 & & \\
\hline Protozoa $\left(\times 10^{5}\right.$ cells $\left.\mathrm{mL}^{-1}\right)$ & $26.67^{a}$ & $20.00^{b}$ & $10.67^{c}$ & 1.69 & $<0.001$ \\
\hline Rumen pH & 7.14 & 6.96 & 7.00 & 0.06 & 0.122 \\
\hline $\mathrm{NH}_{3}-\mathrm{N}\left(\mathrm{mg} 100 \mathrm{~mL}^{-1}\right)$ & $18.37^{a}$ & $16.05^{b}$ & $11.96^{c}$ & 0.61 & $<0.001$ \\
\hline Total VFA (mM) & $88.16^{a}$ & $102.75^{b}$ & $91.88^{\mathrm{ab}}$ & 2.33 & 0.036 \\
\hline Acetate & $52.41^{a}$ & $61.96^{b}$ & $53.39^{a}$ & 1.71 & 0.046 \\
\hline Propionate & 23.89 & 27.44 & 27.36 & 0.73 & 0.134 \\
\hline Butyrate & $7.45^{\mathrm{ab}}$ & $8.22^{a}$ & $6.53^{b}$ & 0.26 & 0.034 \\
\hline Acetate : propionate & 2.30 & 2.28 & 1.96 & 0.08 & 0.171 \\
\hline
\end{tabular}

${ }^{*} \mathrm{NH}_{3}-\mathrm{N}$ : ammonia-N. VFA: volatile fatty acids. ${ }^{* \star} \mathrm{S}$ : sunflower oil supplementation $\left(0,33,66 \mathrm{~g} \mathrm{~kg}^{-1} \mathrm{DM}\right), \mathrm{n}=12$ replicates. ${ }^{* \star \star} \mathrm{SEM}$ : standard error of a mean.

a,b,c Means within a row with different subscripts differ $(\mathrm{P}<0.05)$.

Table 2: Performance of crossbreed (Macheng Black x Boer) female goats fed commercial diets with various supplemental sunflower oil

\begin{tabular}{|c|c|c|c|c|c|}
\hline \multirow{2}{*}{$\begin{array}{l}\text { Observed } \\
\text { variables* }\end{array}$} & \multicolumn{3}{|c|}{$\mathrm{S}, \mathrm{g} \mathrm{kg}^{-1} \mathrm{DM}^{* *}$} & \multirow[t]{2}{*}{ SEM $^{\text {t*t }}$} & \multirow[t]{2}{*}{ P-value } \\
\hline & 0 & 33 & 66 & & \\
\hline Initial weight $(\mathrm{kg})$ & 21.09 & 21.84 & 22.78 & 0.74 & 0.690 \\
\hline $\mathrm{DM} I\left(\mathrm{~g} \mathrm{~d}^{-1}\right)$ & $837.61^{a}$ & $935.28^{a b}$ & $971.32^{\mathrm{b}}$ & 24.64 & 0.033 \\
\hline$\left(g\left(\mathrm{~kg}^{0.75}\right)^{-1}\right)$ & 85.11 & 92.58 & 93.15 & 2.75 & 0.485 \\
\hline $\operatorname{ADG}\left(\mathrm{g} \mathrm{d}^{-1}\right)$ & 103.39 & 136.26 & 116.97 & 6.71 & 0.201 \\
\hline $\mathrm{FE}(\mathrm{G} / \mathrm{F})$ & 0.124 & 0.143 & 0.119 & 0.005 & 0.223 \\
\hline
\end{tabular}

${ }^{*} \mathrm{DMI}$ : dry matter intake. ADG: average daily gain. FE (G/F): feed efficiency (gain/feed). ${ }^{* *} \mathrm{~S}$ : sunflower oil supplementation $\left(0,33,66 \mathrm{~g} \mathrm{~kg}^{-1}\right.$ DM), $n=12$ replicates. ${ }^{* *}$ SEM: standard error of a mean. a,b Means within a row with different subscripts differ $(\mathrm{P}<0.05)$.

Table 3: Apparent total tract digestibility of crossbreed (Macheng Black x Boer) female goats fed commercial diets with various supplemental sunflower oil

\begin{tabular}{|c|c|c|c|c|c|}
\hline \multirow[t]{2}{*}{ Digestibility (\%)* } & \multicolumn{3}{|c|}{$\mathrm{S}, \mathbf{g ~ k g}^{-1} \mathrm{DM}^{* *}$} & \multirow[t]{2}{*}{ SEM $^{* \star *}$} & \multirow[t]{2}{*}{ P-value } \\
\hline & 0 & 33 & 66 & & \\
\hline DM & $60.52^{a}$ & $59.50^{a}$ & $55.89^{b}$ & 0.49 & $<0.001$ \\
\hline $\mathrm{CP}$ & $72.90^{\mathrm{a}}$ & $70.70^{b}$ & $69.76^{b}$ & 0.40 & 0.003 \\
\hline EE & $75.41^{\mathrm{a}}$ & $82.10^{b}$ & $84.26^{b}$ & 0.77 & $<0.001$ \\
\hline NDF & 52.17 & 54.71 & 53.12 & 0.48 & 0.137 \\
\hline ADF & $47.17^{a}$ & $47.81^{\mathrm{a}}$ & $43.12^{b}$ & 0.68 & 0.007 \\
\hline GE & $58.13^{a}$ & $58.20^{\mathrm{a}}$ & $53.66^{b}$ & 0.44 & $<0.001$ \\
\hline
\end{tabular}

*DM: dry matter. CP: crude protein. EE: ether extract. NDF: neutral detergent fiber. ADF: acid detergent fiber. GE: gross energy.

${ }^{*} \mathrm{~S}$ : sunflower oil supplementation $\left(0,33,66 \mathrm{~g} \mathrm{~kg}^{-1} \mathrm{DM}\right), \mathrm{n}=12$ replicates. ${ }^{* *}$ SEM: standard error of a mean. ${ }^{a, b}$ Means within a row with different subscripts differ $(P<0.05)$.

acetate: propionate, although no significant. In our study, increased sunflower oil concentration could change rumen parameters and protozoa counts, except rumen $\mathrm{pH}$. These results are in agreement with previous studies ( $\mathrm{Li}$ et al., 2011; Shibata et al., 2011; Talebzadeh et al., 2012; Lin et al., 2013; Li et al., 2015; Ferreira et al., 2016) which using different type of oils and animals. Hartanto et al. (2017) reported that supplementation monensin-sunflower oil in goats could reduce the production of in vitro protozoa counts up to $75.47 \%$ compared to the control, also decrease $\mathrm{NH}_{3}-\mathrm{N}$ but not affect microbial protein. In our study, $\mathrm{NH}_{3}-\mathrm{N}$ concentration was decreased by sunflower oil supplementation, but still in the normal range for the synthesis of microbial protein by microbial rumen. McDonald et al. (2002) reported that concentrations of $\mathrm{NH}_{3}-\mathrm{N}$ in rumen ranged from $8.5-30 \mathrm{mg} 100 \mathrm{~mL}^{-1}$. In addition, the pattern of $\mathrm{NH}_{3}-\mathrm{N}$ concentration was in line with digestibility of CP (Table 3).

Sunflower oil has high contents in unsaturated fatty acids $(89 \%)$ and approximately $11 \%$ saturated fatty acids (NSA, 2017). Baah et al. (2007) and Szumacher-Strabel et al. (2009) stated that the addition of unsaturated fatty acids (i.e. linoleic acid) source could reduce protozoa population in the rumen. Holotrichs and cellulolytic protozoa have low tolerance with high dietary concentration of some fatty acids such as linoleate (Ivan et al., 2001). In the condition protozoa covering by oil, protozoa do not have lipolytic activity as well as bacteria, then metabolic activity of protozoa disrupted and many protozoa die in conditions of high fat in the rumen (Tamminga and Doreau, 1991). Consequently, the proportion of VFA was affected by this condition, because the principal end products of carbohydrate fermentation by protozoa are acetate and butyrate (Williams and Coleman, 1997). Besides that, a decrease in protozoa counts cause decreased symbiosis between ciliate protozoa with methanogens, then increasing the use of hydrogen to propionate formation by rumen bacteria (Hartanto et al., 2017), due to supplementation of sunflower oil.

\section{Animal performance and nutrient digestibility}

Data on performance of crossbreed (Boer x Macheng Black) female goats is presented in Table 2. DMI $(\mathrm{g} / \mathrm{d})$ was significantly $(\mathrm{P}=0.033)$ affected by supplementation of sunflower oil; but it had no effect on DMI $\left(\mathrm{g} / \mathrm{kg}^{0.75}\right.$, $\mathrm{P}=0.485)$, ADG $(\mathrm{P}=0.201)$ and $\mathrm{FE}(\mathrm{P}=0.223)$. Furthermore, the result of DMI $(\mathrm{g} / \mathrm{d})$ shows that S0 was different with S66, but both of supplementation was not different with S33. Apparent total tract digestibility of $\mathrm{DM}(\mathrm{P}<0.001), \mathrm{CP}(\mathrm{P}=0.003)$, $\mathrm{EE}(\mathrm{P}<0.001)$, ADF $(\mathrm{P}=0.007)$ and $\mathrm{GE}(\mathrm{P}<0.001)$ were affected by 
sunflower oil supplementation, wherein S66 was lower than S0 and S33. Sunflower oil supplementation did not affect $(\mathrm{P}=0.137)$ digestibility of NDF. Data on apparent total tract digestibility is presented in Table 3.

Our results on nutrient digestibility have similarity with Bhatt et al. (2011), Blanco et al. (2014) and Cleef et al. (2016). Except digestibility of EE, another nutrient digestibility (DM, CP, NDF, ADF and GE) was reduced by increasing level of sunflower oil, and this effect was more significant by adding S66 in the ration. Bhatt et al. (2011) stated that a reduction in fiber digestion occurred concomitant with a reduction in protozoa counts. 30\% of the total microbial fiber digestions in the rumen are protozoa (Demeyer, 1981). McGinn et al. (2004) reported that decreased fiber digestion due to added sunflower oil $5 \%$ DMI of beef cattle. In the rumen, the process of hydrogenation of the unsaturated fatty acids may be related to that condition. Unsaturated fatty acids will accumulate when the ability of microorganisms to saturate fatty acids is exceeded. Then this condition will interfere on microbial digestion (NRC, 2001; McGinn et al., 2004).

In our study, DMI and digestibility of EE were increased by sunflower oil supplementation. Therefore, the decrease in fiber digestion was offset by the additional digestible energy supplied by the sunflower oil. Thus, total energy intake was not affected by the decrease in nutrient digestibility. Almost all nutrient digestibilities were not different between $\mathrm{S} 0$ and S33, but S66 was lower than both treatments. Moreover, sunflower oil supplementation could increase total VFA in the rumen as energy source of ruminants, although Pilajun and Wanapat (2011) reported that shift in the VFA profile was associated with fiber digestion. That condition cause sunflower oil supplementation could improve ADG and FE, although not significant. That means sunflower oil could be used as energy supply in goat diets. The inclusion of sunflower oil $33 \mathrm{~g} \mathrm{~kg}^{-1} \mathrm{DM}$ (S33) could improve ADG $31.79 \%$ and FE $15.32 \%$, compared S0; then improve ADG $16.50 \%$ and FE $20.17 \%$, compared S66. Therefore, the result of S33 was better than S0 and S66. Furthermore, S33 which increases the fat content of the diet up to $5.13 \%$ is in agreement with Hristov et al. (2013) recommended that the economic feasibility of dietary fat will achieved if maximum inclusion rate in ruminant diets is 6 to $7 \%$ (total fat) of dietary DM.

The lack of the effect of sunflower oil on DMI is not consistent with the results of McGinn et al. (2004) and Wanapat et al. (2011), who found that DMI was decreased by the addition of sunflower oil 5-6\% of DMI of beef cattle and growing swamp buffaloes, respectively. Addition of soybean oil 3\% had no effect on DMI and ADG of lambs (Mao et al., 2010; Peng et al., 2016). However,
Table 4: Blood biochemical parameters of crossbreed (Macheng Black x Boer) female goats fed commercial diets with various supplemental sunflower oil

\begin{tabular}{lccccc}
\hline Observed variables & \multicolumn{3}{c}{$\mathbf{S}, \mathbf{g ~ k g}^{-\mathbf{1}} \mathbf{D M}^{* *}$} & \multirow{2}{*}{ SEM $^{* * *}$} & P-value \\
\cline { 2 - 4 } & $\mathbf{0}$ & $\mathbf{3 3}$ & $\mathbf{6 6}$ & & \\
\hline Glucose $\left(\mathrm{mmol} \mathrm{L}^{-1}\right)$ & 3.09 & 3.22 & 3.21 & 0.05 & 0.244 \\
Cholesterol $\left(\mathrm{mmol} \mathrm{L}^{-1}\right)$ & $1.81^{\mathrm{a}}$ & $1.85^{\mathrm{a}}$ & $2.67^{\mathrm{b}}$ & 0.10 & $<0.001$ \\
Triglyceride $\left(\mathrm{mmol} \mathrm{L}^{-1}\right)$ & 0.21 & 0.31 & 0.42 & 0.04 & 0.068 \\
Total protein $\left(\mathrm{g} \mathrm{L}^{-1}\right)$ & 62.58 & 63.58 & 67.07 & 0.86 & 0.095 \\
BUN (mmol L-1) & 7.10 & 6.81 & 6.53 & 0.19 & 0.405 \\
ALT $\left(\mathrm{IU} \mathrm{L}^{-1}\right)$ & 17.46 & 15.73 & 17.13 & 0.42 & 0.204 \\
AST $\left(I \mathrm{LL}^{-1}\right)$ & 81.53 & 72.61 & 79.37 & 1.69 & 0.126 \\
\hline
\end{tabular}

*BUN: blood urea nitrogen, ALT: alanine transaminase, AST: aspartate transaminase. ${ }^{* *} \mathrm{~S}$ : sunflower oil supplementation $\left(0,33,66 \mathrm{~g} \mathrm{~kg}^{-1} \mathrm{DM}\right)$, $\mathrm{n}=12$ replicates. ${ }^{* * *}$ SEM: standard error of a mean. $\mathrm{a,b}$ Means within a row with different subscripts differ $(P<0.05)$.

Abubakr et al. (2013) reported that DMI, ADG and FE of goats were increased with addition of palm oil $(5 \%$ of DMI). FE of female goats in this study is consistent with results of Al-Shorepy and Alhadramy (2008), who found that FE of Female Emirati goats fed Distichlis grass was 0.129 .

\section{Blood metabolites}

Table 4 shows blood metabolites or blood biochemical parameters of crossbreed (Macheng Black x Boer) female goats. No differences were observed among levels of sunflower oil on serum concentrations of glucose $(\mathrm{P}=0.244)$, triglyceride $(\mathrm{P}=0.068)$, total protein $(\mathrm{P}=0.095)$, BUN $(\mathrm{P}=0.405)$, AST $(\mathrm{P}=0.126)$ and ALT $(\mathrm{P}=0.204)$. Furthermore, sunflower oil supplementation increased cholesterol concentration $(\mathrm{P}<0.001)$, wherein S66 was higher than S0 and S33. However S33 was not different with SO.

In the present study, sunflower oil supplementation increased cholesterol and had no negative effect in other blood metabolites. Similarly with this result, Pilajun and Wanapat (2011) reported that supplementation of coconut oil $50 \mathrm{~g} \mathrm{Kg}^{-1}$ of diet DM had no effect on blood urea nitrogen of swamp buffalo. Supplementation of palm oil until $16 \%$ in a concentrate of Red Sokoto goats had no effect on serum glucose and cholesterol, but increased blood urea nitrogen (Otaru et al., 2011). Furthermore, Cozma et al. (2015) reported that supplementation of hemp seed oil ( $93 \mathrm{~g} \mathrm{day}^{-1}$ or $4.7 \%$ of DMI) in Carpathian goats had no effect on triglyceride, plasma cholesterol, phospholipid concentrations, and the activities of $\gamma$-glutamyltransferase or alanine aminotransferase, but increase concentration of plasma total lipid. In generally, lipid supplementation could increase plasma lipid fractions such as plasma triglycerides or phospholipids (Bernard et al. 2009; Li et al. 2012). In our study, increased level of sunflower oil could increase intake of nutrients including EE. Therefore, an increase in the digestibility of EE cause increased cholesterol of 
serum. This fact is also verified by Beynen et al. (2000) in the goats were fed the diets containing either olive or palm oil, with cholesterol of serum 1.69-2.71 $\mathrm{mmol} \mathrm{L}^{-1}$. In present sutdy, the results of blood metabolites show that no effect on female goats healthy and Bianci et al. (2014) stated that increased cholesterol levels have a positive correlation with progesterone levels, and then may lead to greater reproductive hormone synthesis.

The ALT and AST could use for evaluation of liver function because belonging of the most sensitive enzymes in the hepatocellular injury diagnosis (Pechová et al., 2006; Tibbo et al. 2008). In the cytoplasm of hepatocytes, there is a transaminase enzyme present in high concentrations called ALT (Cozma et al., 2015). In our study, sunflower oil supplementation had no effect on ALT and AST, and then the values of ALT and AST were close to the value ranges 15.3-25.0 $\mathrm{IU} \mathrm{L}^{-1}$ for ALT (Tibbo et al., 2008; Wang et al., 2016) and 50.0-98.2 IU L ${ }^{-1}$ for AST (Taghipoor et al., 2011; Wang et al., 2016). It indicates if there was not hepatocellular injury on goat that gets sunflower oil supplementation in this study.

\section{CONCLUSIONS}

Results from the current study indicated that sunflower oil supplementation could decrease protozoa counts and had no adverse effect on performance, nutrient digestibility, rumen fermentability and blood biochemical parameters. Whereas the best result of ADG and FE are from inclusion sunflower oil $33 \mathrm{~g} \mathrm{~kg}^{-1}$ of DM (S33). Sunflower oil supplementation could improve performance by positively affecting the ruminal on rumen fermentation in crossbred (Boer x Macheng Black) female goats.

\section{ACKNOWLEDGEMENTS}

The study was funded by the Chinese Agricultural Project for Commonweal (No. 201303145). We would like to thank the editor and reviewers for valuable suggestions.

\section{Author's Contributions}

In this research, all authors contributed effectively. Rudy Hartanto designed and achieved experiments and wrote the paper; Liyuan Cai, Jiangkun Yu, and Ji Zhang performed research, analyzed the data and performed data interpretation; Niya Zhang, Lvhui Sun and Deseng Qi supervised the project and revised the manuscript.

\section{REFERENCES}

Abubakr, A. R., A. R. Alimon, H. Yaakub, N. Abdullah and M. Ivan. 2013. Growth, nitrogen metabolism and carcass composition of goats fed palm oil by-products. Small Rumin. Res. 112: 91-96.

Adeyemi, K. D., A. Q. Sazili, M. Ebrahimi, A. A. Samsudin, A. R. Alimon, R. Karim, S. A. Karsani and A. B. Sabow. 2016. Effects of blend of canola oil and palm oil on nutrient intake and digestibility, growth performance, rumen fermentation and fatty acids in goats. Anim. Sci. J. 87: 1137-1147.

Al-Shorepy, S. A and G. A. Alhadrami. 2008. The effect of dietary inclusion of halophyte Distichlis grass hay Distichlis spicata (L.) on growth performance and body composition of Emirati goats. Emirates J. Food Agric. 20(2): 18-27.

Baah, J., M. Ivan, A. N. Hristov, K. M. Koenig, L. M. Roded and T. A. McAllister. 2007. Effects of potential dietary antiprotozoal supplements on rumen fermentation and digestibility in heifers. Anim. Feed Sci. Technol. 137: 126-37.

Bernard, L., M. Bonnet, C. Leroux, K. J Shingfield and Y. Chilliard. 2009. Effect of sunflower-seed oil and linseed oil on tissue lipid metabolism, gene expression, and milk fatty acid secretion in Alpine goats fed maize silage-based diets. J. Dairy Sci. 92: 6083-6094.

Beynen, A. C., J. T. Schonewille, and A. H. M. Terpstra. 2000. Influence of amount and type of dietary fat on plasma cholesterol concentrations in goats. Small Rumin. Res. 35:141-147.

Bhatt, R. S., N. M. Soren, M. K. Tripathi and S. A. Karim. 2011. Effects of different levels of coconut oil supplementation on performance, digestibility, rumen fermentation and carcass traits of Malpura lambs. Anim. Feed Sci. Technol. 164: 29-37.

Bianci, A. E., V. P. Macedo, R. T. Franc, S. T. A. Lopes, L. S. Lopes, L. M. Stefani, A. Volpato, H. L. Lima, D. Paiano, G. Machado and A. S. DaSilva. 2014. Effect of adding palm oil to the diet of dairy sheep on milk production and composition, function of liver and kidney, and the concentration of cholesterol, triglycerides and progesterone in blood serum. Small Rumin. Res. 117: 78-83.

Blanco, C., F. J. Giráldez, N. Prieto, L. Morán, S. Andrés, J. Benavides, M. L. Tejido and R. Bodas. 2014. Effects of dietary inclusion of sunflower soap stocks on nutrient digestibility, growth performance, and ruminal and blood metabolites of light fattening lambs. J. Anim. Sci. 92: 4086-4094.

Chaney, A. L and E. P .Marbach. 1962. Modified reagents for determination of urea and ammonia. Clin. Chem. 8(2): 130-132.

Chilliard, Y. 1993. Dietary fat and adipose tissue metabolism in ruminants, pigs, and rodents: A review. J. Dairy Sci. 76: 3897-3931.

Cleef, F. O. S. V., J. M. B. Ezequiel, A. P. D’Aurea, M. T. C. Almeida, H. L. Perez and E. H. C. B. Van Cleef. 2016. Feeding behavior, nutrient digestibility, feedlot performance, carcass traits, and meat characteristics of crossbred lambs fed high levels of yellow grease or soybean oil. Small Rumin. Res. 137: 151-156.

Cozma, A., S. Andrei, A. Pintea, D. Miere, L. Filip, F. Loghin and A. Ferlay. 2015. Effect of hemp seed oil supplementation on plasma lipid profile, liver function, milk fatty acid, cholesterol, and vitamin A concentrations in Carpathian goats. Czech J. Anim. Sci. 60(7): 289-301.

Demeyer, D. I. 1981. Rumen microbes and digestion of plant cell walls. Agric. Environ. 6: 295-337.

FAOSTAT. 2017. Data of Crops Processed. United Nations: FAO. Available from: http://www.fao.org/faostat/en/\#data/QD. [Last retrieved on 2017 Aug 26].

Ferreira, E. M., A. V. Pires, I.Susin, M. V. Biehl, R. S. Gentil, M. D. O. M. Parente, D. M. Polizel, C. V. D. M. Ribeiro and E. D. Almeida. 2016. Nutrient digestibility and ruminal fatty acid metabolism in lambs supplemented with soybean oil partially replaced by fish oil blend. Anim. Feed Sci. Technol. 216: 30-39.

Fiorentini, G., I. P. C. Carvalho, J. D. Messana, P. S. Castagnino, A. Berndt, R. C. Canesin, R. T. S. Frighetto and T. T. Berchielli. 
2014. Effect of lipid sources with different fatty acid profiles on the intake, performance, and methane emissions of feedlot Nellore steers. J. Anim. Sci. 92: 1613-1620.

Hartanto, R., L. Cai, J. Yu, N. Zhang, L. Sun and D. Qi. 2017. Effects of supplementation with monensin and vegetable oils on in vitro enteric methane production and rumen fermentability of goats. Pak. J. Agric. Sci. 54(3): 693-698.

Hristov, A.N., J. Oh, J. L. Firkins, J. Dijkstra, E. Kebreab, G. Waghorn, H. P. S. Makkar, A. T. Adesogan, W. Yang, C. Lee, P.J. Gerber, B. Henderson and J.M. Tricarico. 2013. Special topics—mitigation of methane and nitrous oxide emissions from animal operations: I. A review of enteric methane mitigation options. J. Anim. Sci. 91: 5045-5069.

Ivan, M., P. S. Mir, K. M. Koenig, L. M. Rode, L. Neill, T. Entz and Z. Mir. 2001. Effects of dietary sunflower seed oil on rumen protozoa population and tissue concentration of conjugated linoleic acid in sheep. Small Rumin. Res. 41: 215-227.

Li, X. Z., R. J. Long, C. G. Yan, H. G. Lee, Y. J. Kim and M. K. Song. 2011. Rumen microbial response in production of CLA and methane to safflower oil in association with fish oil or/and fumarate. Anim. Sci. J. 82 441-450.

Li, X. Z., C. G. Yan, H. G. Lee, C. W. Choi and M. K. Song. 2012. Influence of dietary plant oils on mammary lipogenic enzymes and the conjugated linoleic acid content of plasma and milk fat of lactating goats. Anim. Feed Sci. Technol. 174: 26-35.

Li, X. Z., C. S. Gao, C. G. Yan, S. H. Choi, J. S. Shin and M. K. Song. 2015. Conjugated fatty acids and methane production by rumen microbes when incubated with linseed oil alone or mixed with fish oil and/or malate. Anim. Sci. J. 86: 755-764.

Lin, B., Y. Lu, A. Z. M. Salem, J. H. Wang, Q. Liang and J. X. Liu. 2013. Effects of essential oil combinations on sheep ruminal fermentation and digestibility of a diet with fumarate included. Anim. Feed Sci. Technol. 184: 24-32.

Martin, C., J. Rouel, J. P. Jouany, M. Doreau and Y. Chilliard. 2008. Methane output and diet digestibility in response to feeding dairy cows crude linseed, extruded linseed, or linseed oil. J. Anim. Sci. 86: 2642-2650.

Mao, H. L., J. K. Wang, Y. Y. Zhou and J. X. Liu. 2010. Effects of addition of tea saponins and soybean oil on methane production, fermentation and microbial population in the rumen of growing lambs. Livest. Sci. 129: 56-62.

McDonald, P., R. A. Edwards, J. F. D. Greenhalgh and C. A. Morgan. 2002. Animal Nutrition. 6th ed. Ashford Colour Press Ltd., Gosport (UK).

McGinn, S.M., K. A. Beauchemin, T. Coates and D. Colombatto. 2004. Methane emissions from beef cattle: Effects of monensin, sunflower oil, enzymes, yeast, and fumaric acid. J. Anim. Sci. 82: 3346-3356.

NRC. 2001. Nutrient Requirements of Dairy Cattle. 7th rev. ed. National Academic Press: Washington, DC

NRC. 2007. Nutrient Requirements of Small Ruminants. National Academic Press, Washington, DC.

NSA. 2017. Sunflower Oil Fatty Acids Profile. National Sunflower Association (NSA), Mandan, ND. Available from: https://www. sunflowernsa.com/uploads/35/sunflower-oil-fact-sheet_062510. pdf. [Last retrieved on $2017 \mathrm{Jul} 20$ ].

Ogimoto, K and S. Imai. 1981. Atlas of Rumen Microbiology. Japan Scientific Societies Press, Tokyo

Otaru, S. M., A. M. Adamu, O. W. Ehocheb and H. J. Makun. 2011. Effects of varying the level of palm oil on feed intake, milk yield and composition and postpartum weight changes of Red Sokoto goats. Small Rumin. Res. 96: 25-35.

Palmquist, D. L. 1987. Adding fat to dairy diets. Anim. Health Nutr. 19: 32.

Pechová, A., R. Dvorák and P. Drastich. 2006. Influence of increased lipid content in diet in the form of treated rapeseed meal on the metabolism and milk yield of dairy cows in the first third of lactation. Vet. Med. 51: 346-356.

Peng, Y. J., J. K. Wang, J. Lin and J. X. Liu. 2016. Effect of dietary soybean oil and antioxidants on fatty acids and volatile compounds of tail subcutaneous and perirenal fat tissues in fattening lambs. J. Anim. Sci. Biotechnol. 7: 24.

Pilajun, R and M. Wanapat. 2011. Effect of coconut oil and mangosteen peel supplementation on rumen fermentation, microbial population, and microbial protein synthesis in swamp buffaloes. Livest. Sci. 141: 148-154.

Roy, A., G. P. Mandal and A. K. Patra. 2013. Evaluating the performance, carcass traits and conjugated linoleic acid content in muscle and adipose tissues of Black Bengal goats fed soybean oil and sunflower oil. Anim. Feed Sci. Technol. 185: 43-52.

SAS. 2008. Statistical Analytical System. Version 9.2. Cary, NC (USA): SAS Institute Inc.

Shibata, H., N. Hashizume, M. R. Gazi, K. Sera, E. Kato, T. Ohmori, M. Kanbe, Y. Obara, S. Kanda, Y. Kurokawa and H. Itabashi. 2011. Effect of supplementation of soy sauce oil and Ca salts of fatty acids on rumen fermentation, milk production and conjugated linoleic acid in milk of dairy cow. Anim. Sci. J. 82: 554-559.

Szumacher-Strabel, M., A. Cieślak and A. Nowakowska. 2009. Effect of oils rich in linoleic acid on in vitro rumen fermentation parameters of sheep, goats and dairy cows. J. Anim. Feed Sci. 18: $440-452$.

Taghipoor, B., H. A. Seifi, M. Mohri, N. Farzaneh and A. A. Naserian. 2011. Effect of prepartum administration of monensin on metabolism of pregnant ewes. Livest. Sci. 135: 231-237.

Talebzadeh, R., D. Alipour, M. J. Saharkhiz, A. Azarfar and M. Malecky. 2012. Effect of essential oils of Zataria multiflora on in vitro rumen fermentation, protozoal population, growth and enzyme activity of anaerobic fungus isolated from Mehraban sheep. Anim. Feed Sci. Technol. 172: 115-124.

Tamminga, S and M. Doreau. 1991. Lipids and rumen digestion. In: J.P. Jouany (Ed.) Rumen Microbial Metabolism and Ruminal Digestion. INRA, Paris, France, pp. 151-163.

Tibbo, M., Y. Jibril, M. Woldemeskel, F. Dawo, K. Aragaw and J. E. O. Rege. 2008. Serum enzymes levels and influencing factors in three indigenous Ethiopian goat breeds. Trop. Anim. Health Prod. 40: 657-666.

Wanapat, M., C. Mapato, R. Pilajun and W. Toburan. 2011. Effects of vegetable oil supplementation on feed intake, rumen fermentation, growth performance, and carcass characteristic of growing swamp buffaloes. Livest Sci. 135: 32-37.

Wang, S. P., W. J. Wang and Z. L. Tan. 2016. Effects of dietary starch types on rumen fermentation and blood profile in goats. Czech J. Anim. Sci. 6(1): 32-41.

Williams, A. G and G. S. Coleman. 1997. The rumen protozoa. In: Hobson, P. N and C. S. Stewart (Eds.). The Rumen Microbial Ecosystem. Blackie Academic and Professional, New York, pp. 73-139.

Yang, M. H and Y. M. Choong. 2001. A rapid gas chromatographic method for direct determination of short-chain (C2-C12) volatile organic acids in foods. Food Chem. 75:101-108. 